Дидактические основы методов обучения / Исаак Яковлевич Лернер. - Москва, 1981. - 186 с. 8. Стронг А. В. Англо-русский, русско-английский словарь с транскрипцией в обеихчастях / А. В. Стронг. - Москва : Аделант, 2014. - 800 с. 9. Фурса В. М. Семантико-граматичне та словотвірне освоєння невідмінюваних імен: дис. на здобуття наук. ступеня канд. філол. наук / спец. 10.02.01 - українська мова / Фурса Валентина Миколаївна; Інститут української мови НАН України. - Київ, 2004. - 224 с. 10. Dictionnairefrar६ais - ucrainien : prèsde 22000 mont / red. B. I. Bourbelo. - Kyiv, 1989. - 415 p.

Ксенія Морозова, Наталія Зеленкова

\title{
РОЗВИТОК ІНФОРМАЦІЙНО-КОМУНІКАЦІЙНИХ КОМПЕТЕНТНОСТЕЙ МАГІСТРАНТІВ НА ЗАСАДАХ МІЖДИСЦИПЛІНАРНИХ ЗВ’ЯЗКІВ
}

Морозова К. О., Зеленкова Н. I. Розвиток інформаційно-комунікаційних компетентностей магістрантів на засадах міждисциплінарних зв’язків.

У статті проаналізовано поняття «міждисциплінарність». Розкрито особливості встановлення та дотримання міждисциплінарних зв'язків у контексті розвитку інформаційно-комунікаційних компетентностей магістрантів у процесі вивчення психологопедагогічних дисциплін; розкрито можливі шляхи реалізації міждисциплінарних зв’язків у форматі змішаного навчання.

Ключові слова: інформаційно-комунікаційні компетентності, міждисциплінарність, дидактична умова, психолого-педагогічні дисципліни, інтеграція, комбіноване навчання.

Морозова К. О, Зеленкова Н. I. Развитие информационно-коммуникационных компетентности магистрантов на основе междисциплинарных связей.

В статье проанализированы понятия «междисциплинарность». Раскрыты особенности установления и соблюдения междисциплинарных связей в контексте развития информационно-коммуникационных компетенций магистрантов в процессе изучения психолого-педагогических дисциплин; раскрыто возможные пути реализации междисциплинарных связей в формате смешанного обучения.

Ключевые слова: информационно-коммуникационные компетентности, междисциплинарность, дидактическое условие, психолого-педагогические дисциплины, интеграция, комбинированное обучение.

Morozova K. O., Zelenkova N. I. The development of postgraduates' information and communication competence on the basis of interdisciplinary connections.

The article analyzes the concept of «interdisciplinarity». The features of establishing and maintaining interdisciplinary connections in the context of ICT competencies undergraduates in the study of psycho-pedagogical disciplines; disclosed the possible ways to implement interdisciplinary connections in the form of blended learning.

Key words: information and communication competence, interdisciplinary, didactic condition, psycho-pedagogical discipline, integration, blended learning.

Застосування IKT часто асоціюють насамперед із дистанційною освітою, проте такі технології не менш актуальні і для традиційного навчання. На сьогодні можна виокремити 
нову специфічну форму навчання - blended learning (змішане навчання), коли поєднуються традиційне (аудиторне) та віртуальне навчання на основі мережевих навчальних курсів, інтернет-ресурсів, електронних бібліотек, навчально-методичних мультимедійних матеріалів, тобто за «контактними» (безпосереднє спілкування викладача та студентів, а також студенів між собою) фазами слідують online-фази. Означена форма об’єднує переваги обох типів навчання: наявність прямих соціальних контактів, які $\epsilon$ важливими для опанування психолого-педагогічних дисциплін та ефективність електронного навчання, що дозволяє розвивати інформаційно-комунікаційні компетентності [9]. Тобто blended learning грунтується на гнучкому комбінуванні (у різних пропорціях залежно від характеру дисципліни) навчання в аудиторії із заняттями в мережі. Із позиції вивчення психологопедагогічних дисциплін, які вимагають безпосереднього контакту викладача з аудиторією, спілкування, обговорення та висунення різних думок, вважаємо за доцільне застосування саме такого типу навчання та відповідного до нього методичного забезпечення.

У контексті компетентнісних тенденцій у сучасній педагогічній практиці дослідники інтенсивно розробляють методичні комплекси та посібники. У навчально-виховний процес вищої школи упроваджуються елементи інноваційних педагогічних технологій, відбувається зміщення акценту на досвід і діяльність особистості. Тому звертаємо увагу на основну роль досвіду та самостійної діяльності студентів в умовах компетентісного підходу, це диктує свої вимоги щодо організації процесу навчання. Сучасні нормативні документи Міністерства освіти і науки України визначають самостійну діяльність провідним видом навчальнопізнавальної діяльності студентів, зокрема магістрантів. Навчальний час, відведений на самостійне опрацювання матеріалу, регламентується навчальним планом у межах від 30 \% до 60 \% від загального обсягу навчального часу, відведеного на вивчення дисципліни [1-3]. У робочих навчальних програмах передбачено завдання для самостійної роботи магістрантів у міжсесійний період, завдання практичного характеру, теоретичні питання для самоконтролю, а також для підготовки до складання іспиту (заліку) з дисципліни.

3 огляду на те, що магістрантів готують до розв'язання специфічних професійних завдань, зокрема й інноваційного, педагогічного характеру, особливістю їх самостійної навчальної діяльності визначаємо спрямованість на результативність роботи, усвідомлення і систематизацію навчального матеріалу, набуття певного досвіду. Ураховуючи специфіку дослідження - розвиток IKK магістрантів - нагальною потребою постає застосування студентами під час самостійної роботи відповідних засобів та елементів IKT. Практична частина нашого дослідження грунтується на дисциплінах психолого-педагогічного циклу, що зумовлює можливість лише опосередкованого впливу на інформаційно-комунікаційні компетентності студентів у процесі навчання, при цьому поєднання матеріалу з IKT має задовольняти такі вимоги:

- інформація має бути цікавою, актуальною, стимулювати розвиток IKкомпетентностей;

- інформація повинна бути професійно спрямованою.

Необхідність упровадження IKT та розвитку у студентів відповідних компетентностей щодо роботи з такими технологіями продиктована й основними завданнями Болонського процесу - створення міжнародного глобального освітнього середовища, головною перевагою якого $є$ подання навчального матеріалу в дидактично уніфікованому й формалізованому вигляді та створення умов використання його контенту в будь-якому місці та в будь-який час [3-5] - акцентуємо увагу на поступовому залученні студентів до місцевих електронних ресурсів з дисципліни, вироблення у них поняття та усвідомлення можливостей і переваг 
такого варіанту представлення та збереження інформації, а також оптимізації їх навчальної діяльності (аудиторної та самостійної). Отже, доходимо висновку, що застосування IKT студентами має забезпечуватись на підгрунті принципу міждисциплінарності.

Міждисциплінарність науковцями розглядається як форма організації наукового знання, заснованого на певних зв'язках між науковими дисциплінами, технологіями та методами, які забезпечують розв'язання комплексних науково-технічних проблем. Окреслене поняття характеризується властивостями інтегративності та вимагає синтезу результатів, отриманих у межах різних наукових дисциплін [6, с. 37].

Найбільш повне психолого-педагогічне обгрунтування дидактичної значущості міжпредметних зв'язків дав К. Ушинський. Він доводив, що знання та ідеї черпаються 3 різних навчальних дисциплін і потім узагальнюються [9, с. 11].

Відтак, за мету статті узято обгрунтування розвитку IKK магістрантів на засадах міждисциплінарних зв’язків як дидактичної умови розвитку IKK магістрантів у процесі вивчення психолого-педагогічних дисциплін.

У педагогічній науці використовують поняття «міждисциплінарні» та «міжпредметні» зв’язки, вони вживаються як синоніми тому, що навчальна дисципліна та навчальний предмет синонімічні поняття у вищій та середній школі. Оскільки наше дослідження грунтується на вищій школі, зупиняємося на понятті «міждисциплінарні зв’язки».

Науковці стверджують, що міждисциплінарні зв'язки відображають комплексний підхід до виховання та навчання, який надає можливість виокремити як основні елементи змісту освіти, так і взаємозв'язки між навчальними дисциплінами, вони допомагають сформувати у студентів конкретні знання та включити їх в оперування пізнавальними методами, які мають загальнонауковий характер (абстрагування, моделювання, аналогія, узагальнення тощо) [6-8].

Актуалізація принципу міждисциплінарності у навчальному процесі дозволяє реалізувати такі чинники розвитку ІК-компетентності:

- здатність до розв’язання комплексних завдань на основі міждисциплінарних знань;

- розвиток творчих здібностей за рахунок переносу понять, ідей та способів діяльності з однієї галузі знань в іншу;

- удосконалення способів пізнання та розумової діяльності [3; 7; 8].

У сучасних дослідженнях, присвячених міждисциплінарній взаємодії, можна виокремити такі основні напрямки реалізації означеного принципу:

- створення інтегрованих навчальних курсів;

- розв’язання навчальних завдань методами різних дисциплін;

- залучення студентів до проектної діяльності з акцентом на міждисциплінарних характер проектів;

- застосування методу проблемного навчання тощо [9, с. 10].

До можливих варіантів реалізації означеної дидактичної умови у межах змішаного навчання відносимо face-to-face driver - викладач особисто надає основний обсяг навчального плану, за необхідності додаючи он-лайн навчання; rotation model - відбувається ротація розкладу традиційного очного навчання та самостійного он-лайн навчання (наприклад, через Інтернет за планом посилань, складеним викладачем. в blended-програмі чи на спеціальному сайті) [4-5].

Тому розвиток IKK магістрантів на засадах міждисциплінарних зв'язків передбачає розроблення та систематичне застосування навчального web-ресурсу з дисципліни, зокрема 
для самостійної навчальної діяльності.

Цільове призначення навчального сайту визначається такими основними пунктами:

- ознайомлення студентів із соціальними та науково-практичними проблемами, характерними для навчальної та подальшої професійної діяльності;

- прищеплення студентам активної позиції у навчальній діяльності;

- стимулювання та розвиток уміння самостійно оцінювати ситуації та обирати шляхи для розв'язання поставлених завдань;

- формування та подальший розвиток інформаційно-комунікаційних компетентностей у процесі навчання.

До загальнодидактичних цілей, що ставлять перед навчальним сайтом, можна віднести створення умов для інтелектуального розвитку студентів, а саме: розвиток критичного та логічного мислення, уміння аналізувати ситуацію, узагальнювати та класифікувати дані, прогнозувати розвиток подій на основі отриманої інформації [7-8].

Ураховуючи те, що навчальний матеріал із психолого-педагогічних дисциплін носить творчий характер, студентам у процесі навчання необхідно проявляти уміння мислити, робити висновки, розв’язувати проблемні завдання, пропонувати власні варіанти дій, тому доцільним $€$ внесення лише окремих елементів IKT до контексту вивчення дисциплін означеного циклу, зокрема електронного навчального ресурсу з дисципліни.

\section{Література}

1. Вітвицька С. С. Теоретичні і методичні засади педагогічної підготовки магістрів в умовах ступеневої освіти: автореф. дис. на здобуття наукового ступеня докт. пед. наук; спец. 13.00.04 «Теорія і методика професійної освіти» / С. С. Вітвицька. - Житомир, 2011. - 40 с. 2. Выготский Л. С. Психологические основы творческой деятельности // Свободное развитие личности школьника: Философские и психолого-педагогические основы образования / сост. В. И. Аксенова, Р. Г. Карандашова. - Ставрополь : СКИПКРО, 2000. 225 с. 3. Волкова Н. П. Педагогіка: [навч. посіб.] / Н. П. Волкова - [3-тє вид., стер.]. - Київ : Академвидав, 2009. - 616 с. 4. Галузинський В. М. Педагогіка: теорія та історія / В. М. Галузинський, М. Б. Євтух. - Рівне, 2003. - 185 с. 4. Краснова Т. И. Смешанное обучение как новая форма организации языкового образования в неязыковом вузе [Електронний ресурс] / Т. И. Краснова - Режим доступу : http://cyberleninka.ru/article/n/ smeshannoe-obuchenie-kak-novaya-forma-organizatsii-yazykovogo-obrazovaniya-v-neyazykovomvuze. 5. Третько В. В. Міждисциплінарний підхід у підготовці майбутніх магістрів міжнародних відносин [Електронний ресурс] / В.В.Третько // Освіта дорослих: теорія, досвід, перспективи. - 2013. - Вип. 6. - С. 94-102. - Режим доступу: http://nbuv.gov.ua/jpdf/OD_2013_6_13.pdf 6. Третько В. В. Особливості організації навчання за магістерськими програмами 3 міжнародних відносин у Великій Британії [Електронний ресурс]/ В. В. Третько // Педагогіка і психологія професійної освіти. - 2013. - № 4. - С. 234-242. Режим доступу : http://nbuv.gov.ua/j-pdf/Pippo_2013_4_25.pdf 7. Ульянова О. В. Междисциплинарность как основопологающий принцип формирования профессиональной компетентности студентов технических вузов [Електронний ресурс] / О.В.Ульянова // Современное образование в России и зарубежом. - 2012. - Режим доступу : http://cyberleninka.ru/article/n/mezhdistsiplinarnost-kak-osnovopolagayuschiy-printsip-formirovaniyaprofessionalnoy-kompetentnosti-studentov-tehnicheskih-vuzov 8. Ушинский К. Д. Избранные педагогические произведения / К. Д. Ушинский. - Москва : Просвещение, 1968. - 558 с. 9. Heinze A. Reflections On The Use Of Blended Learning [Electronic resource] / Aleksej Heinze, 
Chris Procter // Education in a Changing Environment. 13th-14th September 2004. - University of Salford, Salford, Education Development Unit. - 2004. - 11 p. - Mode of access : http: //www.ece.salford.ac.uk/proeedings/papers/ah_04.rtf.

Інна Пащенко

\section{АНАЛІЗ СТАНУ СФОРМОВАНОСТІ НАЦІОНАЛЬНОГО СВІТОГЛЯДУ МАЙБУТНІХ УЧИТЕЛІВ МУЗИКИ}

Пащенко I. М. Аналіз стану сформованості національного світогляду майбутніх учителів музики.

У статті представлено результати стану сформованості національного світогляду майбутніх учителів музики. Проаналізовано критерії, показники сформованості національного світогляду i виявлено рівні його сформованості у межах констатувального експерименту.

Ключові слова: національний світогляд, майбутні вчителі музики, мотиваційний, когнітивно-аксіологічний, діяльнісно-праксеологічний критерії.

Пащенко И. Н. Анализ сформированности национального мировоззрения будущих учителей музыки.

В статье представлены результаты состояния сформированности национального мировоззрения будущих учителей музыки. Проанализированы критерии, показатели сформированности национального мировоззрения и выявлены уровни его сформированности в рамках констатирующего эксперимента.

Ключевые слова. Национальное мировоззрение, будущие учителя музыки, мотивационный, когнитивно-аксиологический, деятельностно-праксеологический критерии.

Paschenko I. N. Analysis of the national ideology formation of future music teachers.

The article presents the cuttent results of national ideology formation of future music teachers. The criteria and indicators of the national ideology formation were analyzed and the levels of its formation in the framework of the ascertaining experiment were determined.

Key words: national ideology, future music teachers, motivational, cognitive-axiological, activity-praxeological criteria.

У роки утвердження незалежності України значними успіхами в розвитку національної педагогічної думки відроджується і визначається досвід національного виховання. Формування національної картини світу як упорядкованої системи уявлень, співвіднесених із певними культурними цінностями нації $€$ засадничим компонентом сучасної освіти в Україні. Національна ідентичність у своїй основі має духовні, культурні цінності, які виражаються через міфологію, філософію, мову, ідеологію, традиції, фольклор, мистецтво тощо.

Як відомо, формування національного світогляду майбутніх учителів музики є одним 3 актуальних завдань сучасної педагогічної освіти. На думку С. Борисової, «національний характер освіти, як пріоритетний напрямок її розвитку, було підкреслено в одному з останніх загальнодержавних документів - «Національній доктрині розвитку освіти», де зазначалося, що освіта має гуманістичний характер, грунтується на культурно-історичних цінностях 